\title{
RHEOLOGICAL PROPERTIES OF POLYMER COLLOID-CELLULOSE THICKENER SYSTEMS
}

\author{
Valentyn Sviderskyi ${ }^{1}$, Liubov Melnyk ${ }^{1}$, \\ Anna Shendera ${ }^{1}$, Hanna Fleisher ${ }^{1, *}$
}

https://doi.org/10.23939/chcht12.02.207

\begin{abstract}
An approach to water emulsions modification with structure forming additives, namely cellulose esters, is proposed in the article. Influence of the film former origin on the system rheological properties at different shear-strain rates was examined. Structural and mechanical, as well as rheological properties of the studied systems were determined. The results confirm that hydroxyethylcellulose has a greater structure forming effect in comparison with carboxymethylcellulose. Hydroxyethylcellulose provides well-definite pseudoplastic properties to the two-component systems that facilitate the production and application of paints. The results of the investigation could be used in the emulsion paint (coatings) production.
\end{abstract}

Keywords: rheological properties, viscosity, polymer colloids, cellulose esters, structural and mechanical properties.

\section{Introduction}

Considering new and stricter ecological claims to paintworks materials (PWM), the manufacture and application of emulsion paints keep steadily growing both in Ukraine and world [1]. Benefits of the emulsion paints are determined by the absence of the organic solvents in their composition (since organic solvents have a negative impact on the environment and consumers health), ease of use, possibility of polymerization at ambient temperature, high performance properties, etc. [2].

Degree of the modern chemical industry development enables improvement of the emulsion paints quality. For example, composition of the emulsion paint along with basic components can contain special additives that improve film forming and layering, and increase

\footnotetext{
${ }^{1}$ National Technical University

of Ukraine "Igor Sikorsy Kyiv Polytechnic Institute",

122, Borchshiagivska St., 03056 Kyiv, Ukraine

*watrushkoo@gmail.com

(C) Sviderskyi V., Melnyk L., Shendera A., Fleisher H., 2018
}

stability and durability of paints and coats [3]. The main role of such additives is to provide special properties to paintwork materials. Among these properties are worth noticing required value of viscosity, no sputtering during layering, required value of thickness at minimal quantity of layers, flexibility and tensile strength, adhesion, protective and heat sensitive properties [4-6].

Among the additives for paintwork materials rheological and texturing ones play an important role. An important function of the rheological additives is to provide required value of viscosity to paints since film forming emulsions are mostly low-viscous liquids. Adjustment and optimization of the paintwork materials rheological properties that determine their handling properties are also important functions of the additives.

Rheological additives are divided into three types depending on the mechanism of the viscosity increase [1]:

- traditional thickeners that have an impact on the water continuous phase;

- additives that increase viscosity by means of structure formation of systems (associative thickeners);

- additives that act as traditional and associative thickeners simultaneously.

Considering a wide variety of rheological additives by mechanism and mode of action cellulose esters are of great interest and also one of the cheapest on the paintwork materials market.

Rheological properties of emulsion paints have significant influence on their performance properties, flowability and shelf life, brushing ability and blotches formation. Rheology of the high-concentration polymer colloids are mostly determined by the formation of a coagulative structure due to the forces of attraction between particles through a continuous phase.

Different factors have an influence on the rheological behavior of the emulsion paints. Increase of the solid phase in the paint causes viscosity and elasticity increase. Generally, surplus of surfactants decreases effective viscosity while the raise of the thickener content 
increases viscosity. Also, origin of the filler surface, fineness and particle form play an important role.

Literature sources pay much attention to investigation of the influence of the filler origin, its particle form and fineness on the rheological properties of the polymer colloids [7]. Also much attention is paid to the study of cellulose, in particular to the structural features of the modified cellulose [46]. There are research works on the investigation of thickening mode of action of cellulose in water solutions [8-10], study of the solutions rheological properties [11-13] and water holding capacity [14-15]. There are rheological studies of the two-component systems that contain epoxy resin and polyurethane film formers [16]. But only few authors focus on the thickener influence on the rheological properties and structure formation in the context of production of paintwork materials [17-20].

However, investigations in this field are up to date for the purpose of rational choice of the thickener for special types of polymer colloids.

The purpose of the conducted investigation is to determine special aspects of the rheological properties and structure formation in the cellulose thickener-polymer colloid system. The following tasks were solved to achieve the purpose:
- to compare properties of polymer colloids and cellulose derivatives;

- to analyze structural, mechanical and rheological properties of the two-component systems that consist of a polymer colloid and a cellulose thickener;

- to determine the impact of the selected thickeners on the structure formation in the studied systems.

\section{Experimental}

A two-component system that consists of a polymer colloid and a thickener is the object of the investigation. Polymer colloids are based on the most widely used film formers: styrene-acrylic (SA) trademark Akronal 290 D and styrene-butadiene (SB) trademark UCARLatex 2012 (Table 1).

The following derivatives of cellulose esters are chosen as thickeners: carboxymethyl cellulose (CMC) and hydroxyethyl cellulose (HEC) QP $30000 \mathrm{H}$ Cellosize of different types depending on mode and mechanism of action (Table 2).

Rheological properties of the two-component systems were studied using coaxial cylinder viscosimeter Rheotest-2. Analysis of structural and mechanical properties was conducted using Veiler-Rebinder plastometer with a parallel movement of a plate [21].

Physical properties of film formers

\begin{tabular}{|l|c|c|}
\hline \multirow{2}{*}{ Characteristic property } & \multicolumn{2}{c|}{ Trademark } \\
\cline { 2 - 3 } & Akronal 290 D & UCAR Latex 2012 \\
\hline Content of dry residue, \% & $50 \pm 1$ & $51 \pm 1$ \\
\hline $\mathrm{pH}$ & $7.5-9$ & 5.5 \\
\hline Viscosity (Brookfield RVT, spindle 2 at 50 rpm), MPa·s & $700-1500$ & 200 \\
\hline Low temperature film formation (LTFF), K & 293 & 278 \\
\hline Density, $\mathrm{kg} / \mathrm{m}^{3}$ & 1004 & 1015 \\
\hline Chemical composition & styrene-acrylic & styrene-butadiene \\
\hline
\end{tabular}

Table 2

Physical properties of thickeners

\begin{tabular}{|l|c|c|}
\hline \multicolumn{1}{|c|}{ Characteristic property } & \multicolumn{2}{c|}{ Trademark } \\
\cline { 2 - 3 } & \multicolumn{1}{|c|}{ CMC } & HEC QP 30000H \\
\hline Visual appearance & White or creamy fibers or powder & White or creamy powder \\
\hline $\begin{array}{l}\text { Viscosity of 1\% water solution } \\
\text { (Brookfield LV, spindel 3 at 30 rpm), MPa.s }\end{array}$ & $1000-4000$ & $1500-2400$ \\
\hline $\mathrm{pH}(1 \%$ water solution) & $6-8.5$ & $6-7$ \\
\hline Loss on drying, \% & $5-7$ & 1 \\
\hline Mode of action & anionic & non-ionogenic \\
\hline
\end{tabular}




\section{Results and Discussion}

Studying of deformation was conducted by using two-component systems that consist of a polymer colloid and a thickener (Table 3).

Results of the study of systems 1 and 3 that contain styrene-acrylic film former and different types of cellulose thickener show that according to the mode of deformation development (namely, fast elastic deformation $\varepsilon_{0}$, , slow elastic $\varepsilon_{2}$ ' and plastic $\varepsilon_{1}^{\prime} \tau$ deformations) the systems are of the same $\mathrm{V}$ structural mechanical type that is described by the following inequality $\varepsilon_{1}{ }^{\prime} \tau>\varepsilon_{2}{ }^{\prime}>\varepsilon_{0}$ '. At the same time quantitative values and ratio of the aforementioned deformation types differ significantly (Tables 4-6).

System 1 is characterized by a greater fast elastic deformation development $\varepsilon_{0}^{\prime}\left(3.45 \cdot 10^{8}\right.$ as opposed to $0.75 \cdot 10^{8}$ ), and lesser plastic deformation development $\varepsilon_{1}{ }^{\prime} \tau$ $\left(28.17 \cdot 10^{8}\right.$ as opposed to $\left.43.48 \cdot 10^{8}\right)$.

Higher efficiency of HEC QP $30000 \mathrm{H}$ as a thickener is visualized in higher viscosity of system 1 in comparison with system $3\left(7.1 \cdot 10^{-2}\right.$ as opposed to $\left.4.6 \cdot 10^{-2} \mathrm{~Pa} \cdot \mathrm{s}\right)$, in the increase of relaxation time from 303 to $130 \mathrm{~s}$ and relative Young's modulus $E_{\varepsilon}\left(0.54 \cdot 10^{-3}\right.$ as opposed to $\left.0.41 \cdot 10^{-10} \mathrm{~J} / \mathrm{cm}^{3}\right)$. This confirms the increase of the molecular forces of attraction between the particles of the thickener and film former by means of bridge bonds.

The results show that aforementioned trends are performed also in case of film former exchange but are slightly different. For example, according to the mode of action system 2 is classified as the II structural and mechanical type when $\varepsilon_{2}^{\prime}>\varepsilon_{1}^{\prime} \tau>\varepsilon_{0}^{\prime}$, while system 4 is classified as $\mathrm{V}$ type. Herewith, system 2 differs by significantly greater fast elastic deformation development $\varepsilon_{0}{ }^{\prime}\left(8.51 \cdot 10^{8}\right.$ as opposed to $\left.4.87 \cdot 10^{8}\right)$ and low elastic deformation development $\varepsilon_{2}$ ' $\left(13.33 \cdot 10^{8}\right.$ as opposed to $6.97 \cdot 10^{8}$ ) and lower plastic deformation development $\varepsilon_{1}{ }^{\prime} \tau$ $\left(10.42 \cdot 10^{8}\right.$ as opposed to $\left.19.80 \cdot 10^{8}\right)$. System 2 is characterized by significantly higher viscosity $\eta_{1}\left(19.2 \cdot 10^{-2}\right.$ as opposed to $\left.10.1 \cdot 10^{-2} \mathrm{~Pa} \cdot \mathrm{s}\right)$ and relaxation time (2098 as opposed to $598 \mathrm{~s})$.

Table 3

Composition of two-component system

\begin{tabular}{|c|c|}
\hline System number & Composition \\
\hline 1 & SA + HEC QP 30000H, 4 wt \% \\
\hline 2 & SB + HEC QP 30000H, 4 wt \% \\
\hline 3 & SA + CMC, $4 \mathrm{wt} \%$ \\
\hline 4 & SB + CMC, $4 \mathrm{wt} \%$ \\
\hline
\end{tabular}

Table 4

Structural and mechanical properties of polymer colloids-thickener system

\begin{tabular}{|c|c|c|c|c|c|c|c|c|}
\hline $\begin{array}{c}\text { System } \\
\text { number }\end{array}$ & $\begin{array}{c}\text { Modulus of } \\
\text { fast elastic } \\
\text { deformation } \\
E_{1} \cdot 10^{-4}, \mathrm{~Pa}\end{array}$ & $\begin{array}{c}\text { Modulus of } \\
\text { slow elastic } \\
\text { deformation } \\
E_{2} \cdot 10^{-4}, \mathrm{~Pa}\end{array}$ & $\begin{array}{c}\text { Relative } \\
\text { yield } \\
\text { point } P_{k 1}, \\
\mathrm{~Pa}\end{array}$ & $\begin{array}{c}\text { Maximum } \\
\text { plastic } \\
\text { viscosity } \\
\eta_{1} \cdot 10^{-2}, \mathrm{~Pa} \cdot \mathrm{s}\end{array}$ & Elasticity $\lambda$ & $\begin{array}{c}\text { Plasticity } \\
\frac{P_{k 1}}{\eta_{1}} \cdot 10^{2}, \mathrm{~s}^{-1}\end{array}$ & $\begin{array}{c}\text { Absolute } \\
\text { relaxation } \\
\text { time } \theta_{1}, \mathrm{~s}\end{array}$ & $\begin{array}{c}\text { Relative } \\
\text { Young's } \\
\text { modulus } \\
E_{\varepsilon} \cdot 10^{-10}, \mathrm{~J} / \mathrm{cm}^{3}\end{array}$ \\
\hline 1 & 5.80 & 3.93 & 2.60 & 7.1 & 0.59 & 0.37 & 303 & 0.54 \\
\hline 2 & 2.35 & 1.50 & 2.30 & 19.2 & 0.61 & 0.12 & 2098 & 0.62 \\
\hline 3 & 26.73 & 3.90 & 2.61 & 4.6 & 0.87 & 0.06 & 135 & 0.41 \\
\hline 4 & 4.11 & 2.87 & 2.94 & 10.1 & 0.59 & 0.29 & 598 & 0.63 \\
\hline
\end{tabular}

Table 5

Deformative properties of polymer colloid-thickener system

\begin{tabular}{|c|c|c|c|c|}
\hline \multirow{2}{*}{$\begin{array}{c}\text { System } \\
\text { number }\end{array}$} & $\begin{array}{c}\text { Fast elastic deformation } \\
\varepsilon_{0}^{\prime} \cdot 10^{8}\end{array}$ & $\begin{array}{c}\text { Slow elastic } \\
\text { deformation } \varepsilon_{2} \cdot 10^{8}\end{array}$ & $\begin{array}{c}\text { Plastic deformation } \\
\varepsilon_{1}^{\prime} \tau \cdot 10^{8}\end{array}$ & $\begin{array}{c}\text { Structural and mechanical } \\
\text { type }\end{array}$ \\
\hline 1 & 3.45 & 5.09 & 28.16 & $\mathrm{~V}$ \\
\hline 2 & 8.51 & 13.33 & 10.42 & $\mathrm{II}$ \\
\hline 3 & 0.75 & 5.13 & 43.48 & $\mathrm{~V}$ \\
\hline 4 & 4.87 & 6.97 & 19.80 & $\mathrm{~V}$ \\
\hline
\end{tabular}


Rheological properties of polymer colloid-thickener system

\begin{tabular}{|c|c|c|c|c|}
\hline System number & $\begin{array}{c}\text { Relative dynamic yield point } \\
P_{k 2}, \mathrm{~Pa}\end{array}$ & $\begin{array}{c}\text { Minimal plastic viscosity } \\
\eta_{m}{ }^{X} \cdot 10^{-2}, \mathrm{~Pa} \cdot \mathrm{s}\end{array}$ & $\begin{array}{c}\text { Dynamic plasticity } \\
\Psi \cdot 10^{4}, \mathrm{~s}^{-1}\end{array}$ & $\begin{array}{c}\text { Yielding } \\
1 / \eta_{m}{ }^{X}\end{array}$ \\
\hline 1 & 8.32 & 1.49 & 5.58 & 67.10 \\
\hline 2 & 55.22 & 0.93 & 59.38 & 107.50 \\
\hline 3 & 11.81 & 2.13 & 5.54 & 46.95 \\
\hline 4 & 7.32 & 0.71 & 10.31 & 140.85 \\
\hline
\end{tabular}

Although the developments of the structural and mechanical properties of the studied systems are similar, the intensity of these developments is significantly different due to different types of cellulose thickeners. For example, the systems based on styrene-acrylic film former with HEC QP $30000 \mathrm{H}$ are characterized by 4.6 times higher $\varepsilon_{0}$ ' value in comparison with the systems with CMC and 1.8 times higher $\varepsilon_{0}$ ' value in comparison with the systems based on styrene-butadiene film former. The $\varepsilon_{1}$ ' $\tau$ value is 0.65 and 0.53 times less, respectively. The $\varepsilon_{2}$ ' value is approximately equal to 1 in the systems based on SA and almost 2 times higher in the systems based on SB.

Analysis of the experimental results enables the comparison of the thickener type influence on different film formers. It is evident that the use of HEC QP $30000 \mathrm{H}$ in the styrene-butadiene emulsion is more efficient. This is confirmed by higher (more than 2 times) viscosity of system 2 in comparison with system $1\left(19.2 \cdot 10^{-2}\right.$ as opposed to $\left.7.1 \cdot 10^{-2} \mathrm{~Pa} \cdot \mathrm{s}\right)$, relaxation time (2098 as opposed to $303 \mathrm{~s}$ ) and relative Young's modulus $E_{\varepsilon}$ $\left(0.62 \cdot 10^{-10}\right.$ as opposed to $\left.0.54 \cdot 10^{-10} \mathrm{~J} / \mathrm{cm}^{3}\right)$.

Mode of changes in the systems based on different film formers and CMC are similar to the aforementioned but the degree of these changes is different. Viscosity of system 4 is higher in comparison with system $3\left(10.1 \cdot 10^{-2}\right.$ as opposed to $\left.4.6 \cdot 10^{-2} \mathrm{~Pa} \cdot \mathrm{s}\right)$, relaxation time (598 as opposed to $135 \mathrm{~s}$ ) and relative Young's modulus $E_{\varepsilon}$ $\left(0.63 \cdot 10^{-10}\right.$ as opposed to $\left.0.41 \cdot 10^{-10} \mathrm{~J} / \mathrm{cm}^{3}\right)$.

The results obtained show that HEC QP $30000 \mathrm{H}$ has a significantly higher thickening effect than CMC: viscosity is 2.7 times higher (as opposed to 2.2 times in case of $\mathrm{CMC}$ ) and relaxation time is 7 times higher (as opposed to 4.3 times in case $\mathrm{CMC}$ ).

Rheological behavior of the polymer colloidthickener system was investigated taking into account structural and mechanical properties.

To obtain easy-to-layer paintwork materials it is rational to account properties of the systems at a wide range of shear rate [22-24]. Whole rheological curves that depict dependence between shear stress and shear rate (Fig. 1) enable conclusion that all the systems except system 2 have similar rheological properties.

Shear rate is up to $660 \mathrm{~s}^{-1}$ and the systems $1,3,4$ start to yield at shear stress $1.8,1.1$ and $1.2 \mathrm{~Pa}$, respectively. Shear rate of the system 2 is also up to $660 \mathrm{~s}^{-1}$ but it starts to yield at $18.8 \mathrm{~Pa}$ that is confirmed by the results of the structural and mechanical analysis (the system is classified as the II type). Occurrence of hysteresis in the systems at forward and backward movement confirms formation of the coagulate structures [22].

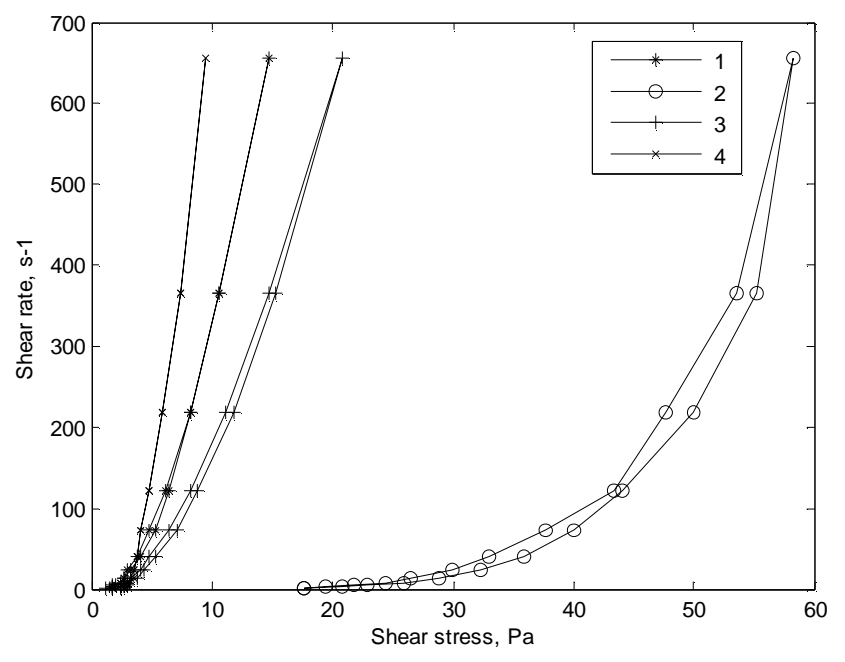

Fig. 1. Rheological curves of polymer colloid-thickener systems: 1, 2, 3, 4 according to Table 1 


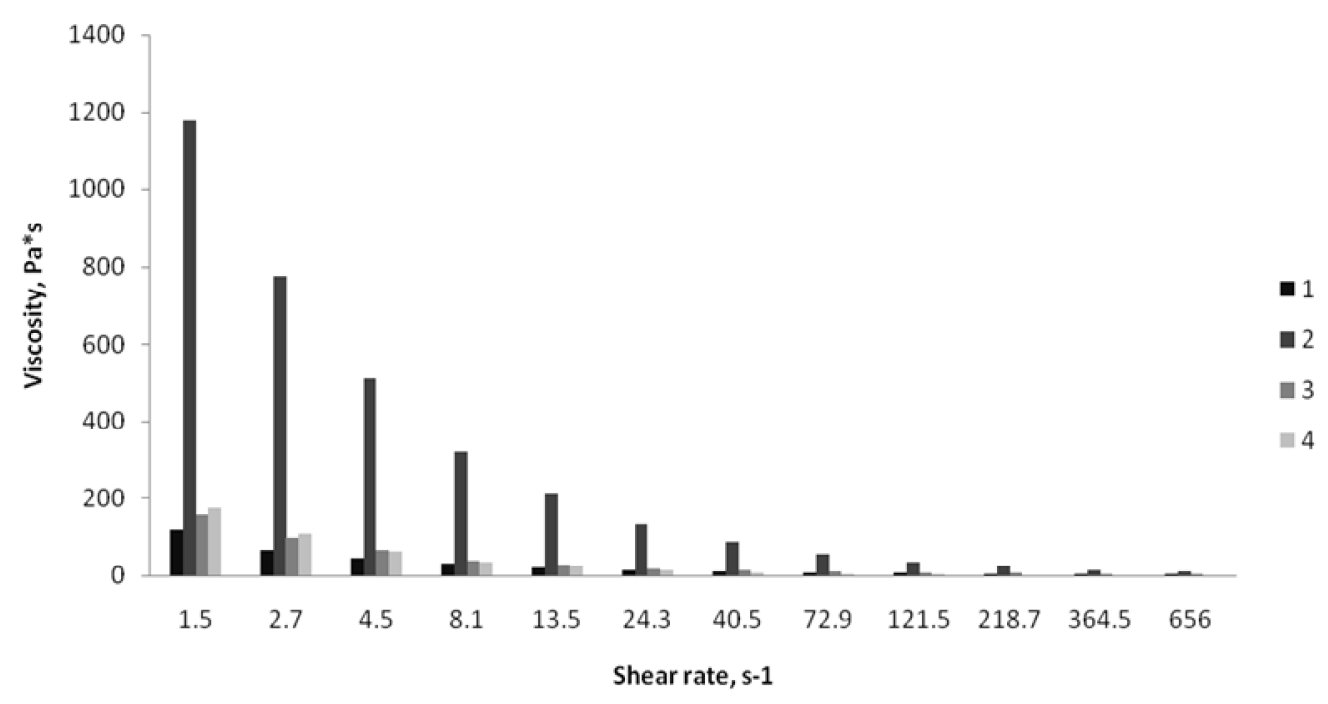

Fig. 2. Viscosity of polymer colloid-thickener systems vs. shear rate: 1, 2, 3, 4 according to Table 1

The systems are thixotropic liquids. Their viscosity decreases when shear stress is applied and reestablishes gradually when the stress is relief (Fig. 2).

Dependence between viscosity and shear rate is very important from the practical point of view since the paint shear stress at the stage of their manufacturing and layering are higher than storage and transport.

\section{Conclusions}

The investigation determined that of four systems three are classified as V structural-mechanical type, and only one, namely styrene-butadiene-hydroxyethylcellulose, is classified as the II type. Herewith the system has the significantly greater relaxation time (2098 s) and approximately 2 times higher viscosity value. The influence of cellulose type at constant film former is studied. It is undeniable that hydroxyethylcellulose has a greater structure forming effect in comparison with carboxymethylcellulose: fast elastic deformation is 4.6 times higher, plastic deformation is 0.65 times lower. Use of the chosen cellulose thickeners enables efficient adjustment of the systems rheological properties. The system yield can occur both at 1.1 or $16.8 \mathrm{~Pa}$, shear rate reaches the value $660 \mathrm{~s}^{-1}$. Cellulose thickeners provides well-definite pseudopastic properties to the two-component systems (high viscosity at low shear rate and low viscosity at shear rate increase) that ease the production and application of paints (resistance to blotches formation increase when layered on the vertical surface).

\section{References}

[1] Brychko A.: Ukr. Lakokras. Zh., 2008, 1, 20.

[2] Sviderkyi V., Karavaiev T.: Nauka i Zhizn, 2011, 1, 4.

[3] http://www.irbis-nbuv.gov.ua/cgi-

bin/irbis_nbuv/cgiirbis_64.exe?C21COM=2\&I21DBN=UJRN\&P21 DBN=UJRN\&IMAGE_FILE_DOWNLOAD=1\&Image_file_name =PDF/Tti_2013_5_8.pdf.

[4] Chobit M., Tokarev V., Voronov S.: Visnyk NU "Lvivska Politekhnika", 2005, 536, 61.

[5] Wu J., Ho H., Sheu M.: European Journal of Pharmaceutical Sciences, 2001, 12, 417. https://doi.org/10.1016/S09280987(00)00196-2

[6] Arhipov A., Pozdnyakov A., Krupin A., Bakanov M.: Tehnika i Tehnol. Pischev. Proizv., 2011, 41, 1.

[7] Myroniuk A., Sikorskyi O., Karavaiev T., Sviderskyi V.: Vost.Evr. Zh. Peredovykh Techn., 2012, 6, 12.

[8] http://vseokraskah.net/vodno-disp-kraski/3-3-4-funkcionalnyedobavki.html

[9] Veen S., Kuijk A., Versluis P. et al.: Langmuir, 2014, 30, 13362. https://doi.org/10.1021/la502790n

[10] Boluk Y., Zhao L., Incani V.: Langmuir, 2012, 28, 6114. https://doi.org/10.1021/la2035449

[11] Iotti M., Gregersen Ø., Moe S., Lenes M.: J. Polym. Environ., 2011, 19, 137. https://doi.org/10.1007/s10924-010-0248-2

[12] Nazari B., Kumar V., Bousfield D., Toivakka M.: J. Rheol., 2016, 60, 1151. https://doi.org/10.1122/1.4960336

[13] Veen S., Versluis P., Kuijk A., Velikov K.: Soft Matter, 2015, 11, 8907. https://doi.org/10.1039/C5SM02086G

[14] Tomer G., Patel H., Podczeck F., Newton J.: Eur. J. Pharm.

Sci., 2001, 12, 321.

[15] Voskoboinikov I., Konstantinova S., Korotkov A.: Rus. J.

Bioorg. Chem., 2013, 39, 694. https://doi.org/10.1134/

S1068162013070145 
[16] Horibe H., Kamimura T., Yoshida K., The Japan Society of Applied Physics, 2005, 44, 1, 4A, 2025-2030.

[17] Melnyk L., Melkonian A., Mizhnarod. Nauk. Zh. "Smart and Young", 2015, 1, 36.

[18] Melnyk L., Savchenko D., Matviienko T.: I Mizhnarod. Konf. Studentiv, Aspirantiv ta Molodykh Vchenykh z Khimii ta Khim. Tekhn. Ukraine, Kyiv 2008, 241.

[19] Melnyk L., Savchenko D., Matviienko T.: II Mizhnarod. Konf. Studentiv, Aspirantiv ta Molodykh Vchenykh z Khimii ta Khim. Tekhn. Ukraine, Kyiv 2009, 166.

[20] Melnyk L., Savchenko D., Matviienko T.: I Mizhnarod. Konf. Studentiv, Aspirantiv ta Molodykh Vchenykh z Khimii ta Khim. Tekhn. Ukraine, Kyiv 2008, 239.

[21] Panda H.: Handbook on Paint Testing Methods, Asia Pacific Business Press Inc., Delhi 2010.

[22] Bauer G., Friedrich C., Gillig C. et al.: J.Roy. Soc. Interface, https://doi.org/10.1098/rsif.2013.0847

[23] Varela Lopez F., Rosen M.: Lat. Am. Appl. Res., 2002, 32, 247.

[24] Noroozi N., Grecov D., Shafiei-Sabet S.: Liq. Cryst., 2014, 41, 55. https://doi.org/10.1080/02678292.2013.834081

Received: May 04, 2017 / Revised: June 30, 2017 / Accepted: November 03, 2017

\section{РЕОЛОГІЧНІ ВЛАСТИВОСТІ СИСТЕМИ ВОДНА ДИСПЕРСІЯ ПОЛІМЕРУ-ЦЕЛЮЛОЗНИЙ ЗАГУСНИК}

\begin{abstract}
Анотація. Запропоновано спосіб модифікації полімерних водних дисперсій за допомогою загусників, а саме естерів целюлози. Досліджено вплив природи плівкоутворюючого агенту на реологічні властивості системи за різного ступеню деформації зсуву. Визначено структурномеханічні та реологічні властивості досліджуваних систем. Встановлено, щзо гідроксиетилиелюлоза є кращии загусником у порівнянні з карбоксиметилцелюлозою. Гідроксиетилцелюлоза надає двокомпонентним системам більш чітко визначені псевдопластичні властивості, щзо полегшуе виробництво та застосування фарб. Результати дослідження можуть бути використані при виробництві водоемульсійних лакофарбових покриттів.
\end{abstract}

Ключові слова: реологічні властивості, в'язкість, водна дисперсія полімеру, естер целюлози, структурномеханічні властивості. 